\title{
ФОРМУВАННЯ БАР'ЄРНОЇ КОМПЕТЕНТНОСТІ МАЙБУТНІХ ВИХОВАТЕЛІВ ЗАКЛАДУ ДОШКІЛЬНОї ОСВІТИ
}

\author{
Дурманенко О. Л. \\ кандидат педагогічних наук, дочент, \\ доиент кафедри загальної педагогіки та дошкільної освіти \\ Волинський національний університет імені Лесі Украйнки \\ пр. Волі, 13, Луиьк, Україна \\ orcid.org/0000-0001-9434-4442 \\ ksu.sagan@gmail.com
}

\author{
Ключові слова: бар'єр, \\ педагогічний бар' $є$, \\ комунікативний бар'єр, \\ професійна компетентність, \\ бар'єрна компетентність \\ майбутнього вихователя.
}

\begin{abstract}
Проблема формування бар'єрної компетентності особистості як складової частини професійної компетентності майбутнього фахівця $\epsilon$ надзвичайно своєчасною для вирішення. Актуалізується ця проблема у дослідженні професійної діяльності майбутніх вихователів сучасного закладу дошкільної освіти, яка грунтується виключно на міжособистісній взаємодії вихователя, дітей та їхніх батьків. Метою статті $€$ аналіз процесу формування бар'єрної компетентності майбутніх вихователів як здатності попереджувати й конструктивно долати різні професійні бар'єри.

3 аналізу тлумачення вченими досліджуваного поняття й з урахуванням специфіки професійної діяльності бар'єрну компетентність майбутнього вихователя визначено як сформовану особистісну здатність майбутнього фахівця дошкільної освіти успішно виконувати свою професійну діяльність, попереджуючи або конструктивно долаючи професійні бар'єри. Компонентами бар'єрної компетентності визначено мотиваційноціннісний, пізнавально-інформаційний, діяльнісно-комунікативний i рефлексивно-саморегулятивний складники, які найбільш повно відображають особливості готовності майбутніх вихователів до професійної діяльності в сучасних закладах дошкільної освіти.

Формування бар'єрної компетентності майбутнього вихователя закладу дошкільної освіти $є$ цілеспрямованим, складним процесом набуття професійних знань, формування практичних умінь i навичок міжособистісної взаємодії з дітьми, їхніми батьками, колегами, громадськістю, а також системним самопізнанням і самовдосконаленням, які дають змогу майбутньому вихователю своєчасно діагностувати наявність тих чи інших бар'єрів і конкретно визначити шляхи їх подолання. Алгоритмом формування бар'єрної компетентності майбутнього вихователя є: мотивація професійної діяльності й формування професійно ціннісної спрямованості особистості вихователя; формування системи професійних (психолого-педагогічних і методичних) знань; набуття практичних умінь і навичок; формування комунікативних умінь; самопізнання та самоаналіз із розробленням програми самовдосконалення.
\end{abstract}




\title{
FORMATION OF BARRIER COMPETENCE OF FUTURE TEACHERS OF PRESCHOOL EDUCATION INSTITUTION
}

\author{
Durmanenko O. L. \\ Candidate of Pedagogical Sciences, Associate Professor, \\ Associate Professor at the Department of General Pedagogy and Preschool Education \\ Lesya Ukrainka Volyn National University \\ Voli avenue, 13, Lutsk, Ukraine \\ orcid.org/0000-0001-9434-4442 \\ ksu.sagan@gmail.com
}

\begin{abstract}
Key words: barrier, pedagogical barrier, communication barrier, professional competence, barrier competence of the future educator.
\end{abstract}

The problem of forming the barrier competence of the individual as a component of the professional competence of the future specialist is extremely timely to solve. This problem is actualized in the study of professional activity of future educators of a modern preschool institution, which is based exclusively on the interpersonal interaction of the educator and children and their parents. The aim of the article is to analyze the process of formation of barrier competence of future educators as the ability to prevent and constructively overcome various professional barriers.

From the analysis of the interpretation of the studied concept by scientists and taking into account the specifics of professional activity, the barrier competence of the future educator is defined as the formed personal ability of the future preschool specialist to successfully perform his professional activity, preventing or constructively overcoming professional barriers. The components of barrier competence are the following components: motivational-value, cognitiveinformational, activity-communicative and reflexive-self-regulatory, which most fully reflect the peculiarities of the readiness of future educators for professional activity in modern preschool institutions.

The formation of barrier competence of the future educator of preschool education is a purposeful, complex process of acquiring professional knowledge, formation of practical skills and skills of interpersonal interaction with children, their parents, colleagues, the public, as well as systematic self-knowledge and self-improvement. the presence of certain barriers and specifically identify ways to overcome them.

The algorithm of formation of barrier competence of the future educator is: motivation of professional activity and formation of professional value orientation of the educator's personality; formation of a system of professional (psychological, pedagogical and methodological) knowledge; acquisition of practical skills and abilities; formation of communicative skills; self-knowledge and self-analysis with the development of a program of self-improvement. 
Постановка проблеми. У період реформування системи вищої освіти все більш актуальним $€$ компетентнісний підхід до професійної підготовки майбутніх фахівців. Йдеться про формування професійної компетентності фахівця як особистісної здатності не лише грунтовно та усвідомлено володіти системою фахових знань, а й успішно, креативно реалізовувати їх у практичній діяльності. Так, Стандарт вищої освіти України першого (бакалаврського) рівня, галузі знань 01 «Освіта/Педагогіка» спеціальності 012 «Дошкільна освіта» [11] передбачає формування інтегральної компетентності як «здатності розв'язувати складні спеціалізовані завдання та практичні проблеми в галузі дошкільної освіти 3 розвитку, навчання i виховання дітей раннього i дошкільного віку, що передбачає застосовування загальних психолого-педагогічних теорій і фахових методик дошкільної освіти, та характеризується комплексністю і невизначеністю умов» й низки загальних та фахових компетентностей.

Аналіз практичної діяльності сучасного вихователя закладу дошкільної освіти, його професійної підготовки свідчить про те, що важливим складником професійної компетентності є здатність особистості майбутнього вихователя попереджувати, діагностувати або ж конструктивно долати різні бар'єри, які виникають як у процесі освітньої діяльності, так і в практичній роботі. Отже, актуальною й нагальною для теоретико-практичного вирішення $\epsilon$ проблема формування бар'єрної компетентності.

Аналіз останніх досліджень і публікацій із проблеми. Методологічні засади формування компетентності запобігання та подолання бар'єрів у педагогічній діяльності аналізує I. Глазкова [2]. Так, науковець зауважує, що бар'єрна компетентність майбутнього вчителя $\epsilon$ «інтегрованим особистісним утворенням, що відображає його теоретичну і практичну готовність до здійснення діяльності із запобігання, подолання та штучного створення бар'єрів у навчальному процесі». Далі вчена визначає складники бар'єрної компетентності, а саме: мотиваційно-стимулюючий, когнітивний, діяльнісно-практичний, емоційно-почуттєвий, саморегулюючий та особистісний [2]. Зауважимо, що саме праці I. Глазкової [2] найбільш повно відображають різні аспекти формування бар'єрної компетентності педагогічних працівників.

3 огляду на специфіку діяльності вихователя закладу дошкільної освіти, зокрема його комунікативної діяльності 3 дітьми та їхніми батьками, актуальними є доробки Г. Щілінської [16] стосовно аналізу комунікативних бар'єрів, які є поширеними у міжкультурній взаємодії студентів, та визначення шляхів їх подолання. Своєю чер- гою, О. Матвієнко [6] диференціює інформаційні бар'єри, які також мають місце у діяльності вихователя закладу дошкільної освіти. Чимало уваги дослідженню психологічних бар'єрів приділяє Н. Сопілко, розглядаючи їх як чинник, що заважає успішній реалізації навчально-виховного процесу й виявляється у пізнавальній та комунікативній пасивності суб'єкта навчання [13]. Розкриття сутності й типів психологічних бар'єрів, їхньої ролі у діяльності людини, у професійному самовизначенні особистості знаходимо в наукових доробках А. Массанова [7].

I. Коновальчук аналізує проблему підготовки майбутніх фахівців дошкільної освіти на засадах компетентнісного підходу [5, с. 65-72]. Своєю чергою, Т. Сваталова окреслює низку компетенцій, якими мають володіти фахівці дошкільної освіти: аналітична, прогностична, проєктивна, оціночна, рефлексивна, інформаційна, розвивальна, орієнтаційна, мобілізаційна, перцептивна, педагогічної техніки та педагогічної взаємодії [12].

Отже, аналіз публікацій із різних аспектів дослідження свідчить про те, що проблема формування здатності майбутнього фахівця до попередження та усунення бар'єрів не нова й існує чималий науковий доробок, спрямований на іiі вирішення. Однак, на нашу думку, недостатньо уваги приділено формуванню готовності майбутнього вихователя попереджувати, діагностувати й конструктивно долати різні бар'єри, з якими вони зустрічаються як в освітньому процесі у ЗВО, так і в професійній діяльності (наприклад, під час проходження виробничих практик у закладі дошкільної освіти). Тому метою статті $\epsilon$ аналіз проблеми формування бар'єрної компетентності майбутніх вихователів ЗДО як складової частини їхньої професійної компетентності. Для iii досягнення необхідно вирішити низку завдань: 1) розкрити сутність поняття бар'єрної компетентності майбутнього вихователя ЗДО та її структури; 2) з аналізу специфіки майбутньої професійної діяльності вихователя ЗДО визначити основні види бар'єрів; 3) запропонувати алгоритм формування бар'єрної компетентності майбутніх вихователів ЗДО. Основними методами дослідження нами визначено: аналіз, синтез, узагальнення та конкретизація.

Виклад основного матеріалу. Аналіз психолого-педагогічної літератури свідчить про те, що сутнісно-функційна характеристика поняття компетентності відображена в наукових дослідженнях І. Беха, С. Гончаренка, Н. Кузьміної, А. Маркової, А. Хуторського та ін. Конструктивними у контексті нашого дослідження $є$ ідеї стосовно змісту й структури професійно-педагогічної компетентності, запропоновані вченими О. Антоновою, О. Дубасенюк, Т. Семенюк, які дану компе- 
тентність розглядають як складне утворення, що містить знаннєву компетентність у галузі теорії навчання та виховання; соціально-психологічну компетентність у галузі комунікації; диференційно-психологічну компетентність в особистісній сфері мотивації та цінностей; аутопсихологічну компетентність у сфері надбань, переваг і недоліків власної діяльності й особистості [3, с. 7].

Аналіз різних питань професійної підготовки майбутніх спеціалістів дошкільної освіти знаходимо у доробках учених Г. Бєлєнької, А. Богуш, Л. Загородньої, Н. Денисенко, І. Дичківської, Є. Карпової, Н. Лисенко, Л. Машкіної, Л. Пісоцької, Т. Поніманської, О. Семенова, Н. Семенової та ін. Зауважимо, що названі вчені проблему професійної підготовки майбутніх вихователів розглядають на засадах компетентнісного підходу. Також зазначимо, що єдиного визначення компетентності фахівця дошкільного закладу, іiі структурних компонентів немає. Так, професійну компетентність майбутнього вихователя Г. Бєлєнька тлумачить як «професійну підготовленість і здатність суб'єкта праці до виконання завдань і обов'язків повсякденної діяльності. Вона зумовлена когнітивним та діяльнісним компонентами підготовки фахівця, виступає мірою й основним критерієм визначення його відповідності умовам праці» [1, с. 35]. Далі вчена зауважує, що професійна компетентність педагога-вихователя дітей дошкільного віку охоплює такі сфери компетенції, як оздоровчо-профілактична, діагностико-прогностична, навчально-розвивальна, методична, виховна, комунікативна, організаційно-педагогічна, контрольна, просвітницька, самовдосконалення, кожна 3 яких потребує від вихователя, крім професійних знань та вмінь, ще й наявності позитивних світоглядних настанов і розвитку певних особистісних професійно значущих рис характеру [1]. Цей перелік А. Машкіна доповнює ще компетентністю у сфері застосування педагогічних інновацій, зокрема таких іiі компонентів, як поінформованість, грамотність, культура, позиція студентів щодо використання інноваційних педагогічних технологій у дошкільних закладах [8, с. 129-136]. Для успішного вирішення питання формування елементарних навиків здорового способу життя у дітей дошкільного віку В. Нестеренко пропонує формувати професійно-валеологічну компетентність як складову частину загальної професійної компетентності майбутнього вихователя-педагога, яка конкретизує його теоретичну і практичну підготовку щодо розв'язання питань, пов'язаних із вихованням у дошкільників навичок здорового способу життя [9].

Ураховуючи специфіку майбутньої професійної діяльності вихователя у закладі дошкільної освіти (зокрема, міжособистісної взаємодії педа- гога 3 дітьми та їхніми батьками, міжособистісного спілкування у системі «педагог - дошкільник - родина»), доречним, на нашу думку, $\epsilon$ формування компетентності попередження та долання професійних бар'єрів.

Як нами вже було зазначено, сутність і структуру бар'єрної компетентності педагога визначила I. Глазкова [2, с. 109-116]. Своєю чергою, поняття педагогічного бар'єру пропонує Л. Ярославська, тлумачачи його як складне поліаспектне педагогічне явище, зумовлене зовнішніми та внутрішніми чинниками, властиве всім суб' єктам освітнього процесу й яке перешкоджає його успішності та ефективності [15]. Універсальність цього визначення дає змогу об'єктивно-суб'єктивні перешкоди успішної педагогічної діяльності майбутніх вихователів визначити як професійні бар'єри. Тоді, сформовану (тобто набуту) особистісну здатність майбутнього вихователя закладу дошкільної освіти успішно виконувати свою професійну діяльність, попереджуючи або конструктивно долаючи професійні бар'єри, нами буде інтерпретовано як їхню бар'єрну компетентність.

Ми підтримуємо думку вчених про те, що бар'єрна компетентність майбутніх вихователів $є$ результатом їхньої професійної підготовки. Компонентами бар'єрної компетентності нами визначено такі складники, як: мотиваційно-ціннісний, пізнавально-інформаційний, діяльнісно-комунікативний та рефлексивно-саморегулятивний. На нашу думку, визначені компоненти найбільш повно відображають специфіку готовності майбутніх вихователів до професійної діяльності в сучасних закладах дошкільної освіти.

У контексті особливостей професійної діяльності вихователя закладу дошкільної освіти актуальним, на нашу думку, є визначення бар'єра як перешкоди, що зумовлює опір впливові співрозмовника, запропоноване I. Зязюном [10]. Зокрема, виділення вченим фізичних (просторова й часова дистанція, що відокремлює викладача від студента, вихователя від дошкільника), гностичних (складність, незрозумілість висловлювань, їх несприйняття), естетичних (неналежний зовнішній вигляд), емоційних (негативні емоції, крик, злість), психологічних (негативні установки на підставі попереднього досвіду, особистісне несприйняття, упереджене особистісне ставлення тощо) бар'єрів є дієвим в аналізі педагогічних бар'єрів у діяльності вихователів ЗДО [10].

Аналізуючи професійні бар'єри вихователів закладу дошкільної освіти, нам видається важливою характеристика комунікативних бар'єрів, які Н. Яковлєва пояснює як психологічне явище, що призводить до ускладнення й блокування спілкування у процесі спільної діяльності [14]. 
Попередженням комунікативного бар'єру у педагогічній діяльності майбутнього вихователя є правильно вибраний стиль спілкування 3 дітьми та їхніми батьками, який залежить від особистісних якостей педагога, його ставлення до дітей, володіння організаторськими здібностями тощо [4]. Йдеться, насамперед, про активно-позитивне ставлення вихователя до дітей, його захоплення спільною творчою діяльністю, що передається й вихованцям. Це спонукає до позитивного сприйняття дошкільниками педагога.

Практика діяльності сучасного ЗДО переконливо доводить, що вихователю необхідно уникати власного домінування й визнавати право кожної дитини на думку; дослухатися до суджень батьків дітей; бути готовим змінюватися й занурюватися у світ дитячих емоцій та почуттів; уміти рефлексувати та бути емпатійним; навчитися активно слухати, чути, розуміти, сприймати почуте, використовуючи нестандартні прийоми міжособистісного спілкування. Іншими словами, вихователь має вміти відходити від виключно рольової позиції педагога.

Отже, формування бар'єрної компетентності майбутнього вихователя закладу дошкільної освіти є цілеспрямованим, складним процесом набуття професійних знань, формування практичних умінь і навичок міжособистісної взаємодії $з$ дітьми, їхніми батьками, колегами, громадськістю, а також системним самопізнанням і самовдосконаленням. Саме об'єктивне самопізнання й самоаналіз дають змогу майбутньому вихователю, на нашу думку, своєчасно діагностувати наявність тих чи інших бар'єрів і конкретно визначити шляхи ïx подолання, переважна більшість із яких і зумовлює активне самовдосконалення й саморегуляцію.

Аналізуючи різні психолого-педагогічні джерела, організацію освітнього процесу в закладі вищої освіти, закладі дошкільної освіти, ми пропонуємо такий алгоритм формування бар'єрної компетентності майбутніх вихователів. Насамперед, студент - майбутній вихователь має бути мотивований до професійної діяльності, усвідом-

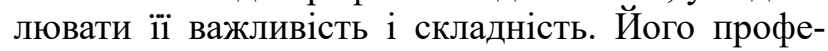
сійною цінністю має стати готовність успішно й майстерно виконувати свої функції. Наступним обов'язковим складником процесу формування бар'єрної компетентності є усвідомлене грунтовне оволодіння майбутнім вихователем системою професійних знань, методичними знаннями, а також знаннями про сутність бар'єру, його види й роль як рушійної сили професійної діяльності особистості, шляхи подолання тощо. Важливим у формуванні бар'єрної компетентності $€$ також наявність практичних професійних умінь і навичок майбутніх вихователів, у тому числі й у подоланні педагогічних бар'єрів. Такі навички студенти набувають не лише під час навчання, а й у позааудиторній роботі (виховній, науково-дослідницькій, під час проходження різного виду педагогічних практик). Особливо важливими $€$ комунікативні вміння майбутніх вихователів, які уможливлюють попередження комунікативних бар'єрів. Не менш актуальним складником формування бар'єрної компетентності майбутніх вихователів є самоаналіз і розвиток комунікативності особистості майбутнього вихователя як провідної професійної якості. Саме в ході самоаналізу студенти вчаться діагностувати свою готовність до майбутньої професійної діяльності у цілому й зокрема до попередження педагогічних бар'єрів, а в разі виникнення - до конструктивного їх долання. Ми особливо акцентуємо на формуванні вмінь студентів за допомогою різних психодіагностичних методик оцінювати власну рефлексивність, емпатійність, організаторські й комунікативні здібності, творчість, комунікабельність, уміння долати бар'єри спілкування та ін.

Майбутні вихователі, аналізуючи різні моделі спілкування (за В. Кан-Каліком та І. Юсуповим): «Монблан», «Китайська стіна», «Локатор», «Гамлет», «Робот», «Друг, «Тетерук», «Я сам», визначають їхні характерні ознаки й обставини, за яких та чи інша модель може бути ефективною і коли iï застосування слугує бар'єром у взаємодії. При цьому майбутні вихователі розробляють власну модель спілкування 3 вихованцями, їхніми батьками, яка б забезпечила успішність і результативність їхньої діяльності.

Діагностуючи власну систему позиційного ставлення «Батько», «Дорослий», «Дитина» (за трансакційною концепцією Е. Берна), майбутні вихователі також попереджують можливість виникнення психологічного бар'єру й розробляють програму самовдосконалення, яка й орієнтована на формування їхньої комунікативної поведінки.

У формуванні бар'єрної компетентності майбутніх вихователів надзвичайно важливою $\epsilon$ комунікативність особистості як професійна якість, що інтегрує в собі вміння чітко, грамотно й доступно висловлювати свою думку, говорити (комунікабельність), потребу в спілкуванні 3 іншими людьми (соціальну спорідненість) та позитивні емоції, радість і задоволення від спілкування (альтруїстичні емоції) (В. Кан-Калік, I. Юсупов). На нашу думку, майбутній вихователь, якому властива комунікативність, зможе успішно не лише попереджувати, а й творчо долати будьякі педагогічні бар'єри.

Висновки. На сучасному етапі реформування вищої освіти провідним $\epsilon$ компетентнісний підхід до професійної підготовки майбутніх фахівців. Професійна компетентність майбутнього вихователя закладу дошкільної освіти передба- 
чає не лише оволодіння ним системою професійних знань, умінь і навичок, а і його здатність фахово, майстерно виконувати свою педагогічну діяльність на засадах співпраці, партнерства, дитиноцентризму.

Професійній діяльності вихователя у сучасному закладі дошкільної освіти притаманні різні педагогічні бар'єри. А отже, його професійна компетентність має містити складник, який відображає здатність майбутнього вихователя до попередження й долання таких перешкод, бар'єрну компетентність.
Бар'єрна компетентність є сформованим складним особистісним утворенням, яке містить мотиваційно-ціннісний, пізнавально-інформаційний, діяльнісно-комунікативний та рефлексивно-саморегулятивний складники. Саме процес професійної підготовки майбутнього вихователя ЗДО має забезпечити формування визначених компонентів бар'єрної компетентності.

Подальшого дослідження потребує розроблення інструментарію та методики діагностування (у тому числі й самодіагностування) сформованості бар’єрної компетентності майбутніх вихователів.

\section{ЛІТЕРАТУРА}

1. Бєлєнька Г.В. Теоретико-методичні засади формування професійної компетентності вихователів дошкільних навчальних закладів в умовах ступеневої підготовки : дис. ... докт. пед. наук : 13.00.08. Київ, 2012. С. 35.

2. Глазкова I. Компетентність запобігання та подолання бар'єрів: методологічні орієнтири дослідження. Наукові записки Кіровоградського державного педагогічного університету імені Володимира Винниченка. Серія «Педагогічні науки». 2013. Вип. 120. С. 109-116

3. Дубасенюк О.А., Семенюк Т.В., Антонова О.С. Професійна підготовка майбутнього вчителя до педагогічної діяльності : монографія. Житомир : Житомир. держ. пед. ун-т, 2003. С. 7.

4. Кан-Калик В.А. Учителю о педагогическом общении. Москва, 1987. С. 97-100, 110, $114-117$.

5. Коновальчук I.I. Підготовка майбутніх фахівців дошкільної освіти на засадах компетентнісного підходу: теоретичний аналіз. Науковий вісник Чернівецьького університету. Серія «Педагогіка та психологія». 2015. Вип. 764. С. 65-72.

6. Матвієнко О.В. Основи інформаційного менеджменту : навчальний посібник. Київ : Центр навчальної літератури, 2004. С. 12-25.

7. Массанов А. Психологічні бар'єри у професійному самовизначенні особистості. Психологія $i$ суспільство. 2014. № 2. С. 73-89.

8. Машкіна Л.А. Професійна підготовка майбутніх фахівців із дошкільної освіти в процесі педагогічної практики. Наукові записки кафедри педагогіки. 2012. Вип. 28(1). С. 129-136.

9. Нестеренко В.В. Підготовка майбутніх педагогів до виховання у дошкільників навичок здорового способу життя : автореф. дис. ... канд. пед. наук. Одеса, 2003. 20 с.

10. Педагогічна майстерність : підручник / І.А. Зязюн та ін. ; за ред. І.А. Зязюна. Київ : Вища школа, 1997. 349 c.

11. Про затвердження стандарту вищої освіти за спеціальністю 012 «Дошкільна освіта» для першого (бакалаврського) рівня вищої освіти : Наказ МОіНУ від 21.11.2019 № 1456. Київ, 2019.

12. Сваталова Т. Профессиональные ключевые компетенции педагога дошкольного образования как основа программ повышения квалификации. URL: pedagoga-doshkolnogo-obrazovaniya-kak-osnovaprogramm-povysheniya-kvalifikatsii (дата звернення: 14.04.2021).

13. Сопілко Н.В. Особливості подолання психологічних бар'єрів у студентів у процесі навчання : автореф. дис. ... канд. психол. наук : 19.00.07. Хмельницький, 2008. 21 с.

14. Яковлева Н.В. Психолого-педагогічні умови подолання комунікативних бар'єрів у процесі вивчення іноземної мови : автореф. дис. ... канд. психол. наук : 19.00.07. Київ, 2003. 20 с.

15. Ярославська Л.І. Дидактичні умови подолання педагогічних бар’єрів у процесі навчального співробітництва викладачів і студентів : дис. ... канд. пед. наук. Харків, 2010. 178 с.

16. Щілінська Г.В. Комунікативні бар’єри у процесі міжкультурної взаємодії студентів та шляхи їх вирішення. Міжнародний науковий форум: соиіологія, психологія, педагогіка, менеджмент. 2015. Вип. 18. С. 50-58.

\section{REFERENCES}

1. Byelyen'ka H.V. (2012) Teoretyko-metodychni zasady formuvannya profesiynoyi kompetentnosti vykhovateliv doshkil'nykh navchal'nykh zakladiv v umovakh stupenevoyi pidhotovky: dys. dokt. ped. Nauk [Theoretical and methodical bases of formation of professional competence of educators of preschool educational institutions in the conditions of degree preparation: dis. Dr. ped. Science]. Kyiv, P. 35.

2. Hlazkova I. (2013) Kompetentnist' zapobihannya ta podolannya bar"yeriv: metodolohichni oriyentyry doslidzhennya. [Competence to prevent and overcome barriers: methodological guidelines of the study. Sci- 
entific notes of Kirovograd State Pedagogical University named after Volodymyr Vynnychenko]. Series: Pedagogical sciences. Issue 120. S.109-116

3. Dubasenyuk O.A., Semenyuk T.V., Antonova O.Y. (2003) Profesiyna pidhotovka maybutn'oho vchytelya do pedahohichnoyi diyal'nosti: monohrafiya. [Professional preparation of the future teacher for pedagogical activity: monograph.] Zhytomyr. state ped. un-t, S. 7

4. Kan-Kalyk V.A. (1987) Uchytelyu o pedahohycheskom obshchenyy. [To the teacher about pedagogical communication]. Moscow, P.97-100, 110, 114-117.

5. Konoval'chuk I.I. (2015) Pidhotovka maybutnikh fakhivtsiv doshkil'noyi osvity na zasadakh kompetentnisnoho pidkhodu: teoretychnyy analiz. [Training of future specialists of preschool education on the basis of the competence approach: theoretical analysis]. Scientific Bulletin of Chernivtsi University. Series: Pedagogy and psychology. Vip. 764. Chernivtsi: Chernivtsi National University. Univ., S. 65-72.

6. Matviyenko O.V. (2004) Osnovy informatsiynoho menedzhmentu : navch. posib. [Fundamentals of information management: textbook. way]. Kyiv: Center for Educational Literature, P.12-25.

7. Massanov A. (2014) Psykholohichni bar"yery u profesiynomu samovyznachenni osobystosti. Psykholohiya i suspil'stvo. [Psychological barriers in professional self-determination]. Psychology and society. № 2. P.73-89.

8. Mashkina L.A. (2012) Profesiyna pidhotovka maybutnikh fakhivtsiv z doshkil'noyi osvity v protsesi pedahohichnoyi praktyky. Data zvernennya 14.04.2021. [Professional training of future specialists in preschool education in the process of pedagogical practice]. Scientific notes of the department of pedagogy. Issue 28 (1). S.129-136.

9. Nesterenko V.V. (2003) Pidhotovka maybutnikh pedahohiv do vykhovannya u doshkil'nykiv navychok zdorovoho sposobu zhyttya : avtoref. dys. kand. ped. nauk. [Preparation of future teachers for the education of preschoolers in healthy lifestyle skills]. author's ref. dis. Cand. ped. Science. Odessa, 2003. 20 p.

10. Pedahohichna maysternist': Pidruchnyk /I.A. Zyazyun, L.V. Kramushchenko, I.F. Kryvonos ta in.; za red. I.A. Zyazyuna. Kyyiv: Vyshcha shkola. (1997) .[ Pedagogical skills]. Textbook / IA Zyazyun, LV Kramushchenko, IF Krivonos, etc .; for order. IA Zyazyun. Kyiv: Higher School, 1997. 349 p.

11. Pro zatverdzhennya standartu vyshchoyi osvity za spetsial'nistyu 012 «Doshkil'na osvita» dlya pershoho (bakalavrs'koho) rivnya vyshchoyi osvity. (2019) [About the statement of the standard of higher education on a specialty 012 "Preschool education" for the first (bachelor's) level of higher education]. Order of the Ministry of Education and Science of Ukraine №1456, Kyiv.

12. Svatalova T. (2021) Professyonal'nye klyuchevye kompetentsyy pedahoha doshkol'noho obrazovanyya kak osnova prohramm povyshenyya kvalyfykatsyy. [Professional key competencies of a preschool teacher as a basis for advanced training programs]. URL:pedagoga-doshkolnogo-obrazovaniya-kak-osnova-programm-povysheniya-kvalifikatsii.

13. Sopilko N.V. (2008) Osoblyvosti podolannya psykholohichnykh bar"yeriv u studentiv u protsesi navchannya : avtopef. dys. [Peculiarities of overcoming psychological barriers in students in the learning process]. autof. dis. for science. degree of Cand. psychol. Science: special. 19.00.07. Khmelnytsky. 21p.

14. Yakovleva N.V. (2003) Psykholoho-pedahohichni umovy podolannya komunikatyvnykh bar"yeriv u protsesi vyvchennya inozemnoyi movy : avtopef. dys. [Psychological and pedagogical conditions for overcoming communication barriers in the process of learning a foreign language]. autof. dis. for science. degree of Cand. psychol. Science: special. 19.00.07. Kyiv, 20p.

15. Yaroslavs'ka L.I. (2010) Dydaktychni umovy podolannya pedahohichnykh bar"yeriv u protsesi navchal'noho spivrobitnytstva vykladachiv i studentiv: dys. kand. ped. nauk. [Didactic conditions for overcoming pedagogical barriers in the process of educational cooperation of teachers and students]. dis. Cand. ped. Science. Kharkiv, $178 \mathrm{p}$.

16. Shchilins'ka H.V. (2015) Komunikatyvni bar"yery u protsesi mizhkul'turnoyi vzayemodiyi studentiv ta shlyakhy yikh vyrishennya. [Communication barriers in the process of intercultural interaction of students and ways to solve them]. International scientific forum: sociology, psychology, pedagogy, management. Issue 18. Pp. 50-58. 